countries. In 1949 the estimated budget of the Organisation is $7,000,000$ dollars; in 1950 it is proposed to spend $17,000,000$ dollars. This would be made up of a regular budget of less than $8,000,000$ dollars to be financed by contributions from member states and a supplemental operating programme of technical and advisory services costing a little more than $9,000,000$ dollars which would be financed by voluntary additional contributions to the World Health Organisation from member states. The latter programme would cover new health projects and extend the range of the existing programme. Details of the new projects and other activities of the Organisation are described in the Chronicle which is published monthly in English, French, Russian, Spanish and Chinese 20

\section{Fuzz-Hairs of Cozton-Seed}

Mr. O. M. ABDELhaF to of the Fouad I Agricultural Museum, Daki, ofine, writes that when examining 'neps' teflen from Dotton yarn it was noticed that fuzz-hys attacked to testa fragments kept such stains as Iodim Green after washing, while the linthairs lost die colour. Microtome sections of ovules staled Methyl Green and Congo Fed showed fuzz lairs beginning to form on the fifth day after flowering, with blue or violet cytoplasm which contrasted sharply with the five-day-old lint-hairs, the walls of which were red. No fuzz-hairs were observed earlier than this.

\section{University of London: Appointments}

THe following appointments in the University of London haye been announced : Dr. Joseph Rotblat, to the University chair of physics tenable at St. Bartholomew's Hospital Medical College, from Janu$\operatorname{ary} 1,1950$; Dr. A. C. Cunliffe, to the University readership in bacteriology tenable at King's College Hospital Medical School, from October 1, 1949; Mr. J. L. Malcolm, to the University readership in experimental physiology tenable at St. Mary's Hospital Medical School, from October 1, 1949.

\section{Colonial Service : Recent Appointments}

THE following appointments in the Colonial Service have been announced: T. J. L. Bates, agricultural officer, T/nganyika; J. J. Davies, agricultural officer, Tanganyika; D. J. McCrae, entomologist, Kenyz; N. E. S. Mutter, agricultural officer, Tanganyika; D. G. Cooper, assistant electrical engineer, Public Works Department, Nyasaland; F. Hobgood, geologist, Nyasaland; D. N. Sampson, geologist, Tanganyika; A. O. Stickings, surveyor, Sarawak; T. Pettifer, veterinary officer, Tanganyika; D. A. Walker, veterinary officer, Kenya; D. F. Bargman, meteorologist, East African High Commission; W. L. D. Diaper, government chemist, Mauritius; I. G. Mathers, agricultural development officer, Nigeria; Miss J. Tyrell, statistical officer, Nigeria; M. Akenhead (agricultural officer, Gold Coast), senior agricultural officer, Gold Coast; J. A. Allan (pasture research officer, Kenya), agricultural officer, Northern Rhodesia; J. Cofie (agricultural officer, Gold Coast), senior agricultural officer, Gold Coast; M. Halcrow (deputy director of agriculture, Barbados), deputy director of agriculture, Nyasaland; J. H. Hinds (agricultural officer, Gold Coast), senior agricultural officer, Gold Coast ; A. Jones (agricultural officer, Gold Coast), senior agricultural officer, Gold Coast; C. J. McK. Krige (agricultural officer, Somaliland Protectorate), senior agricultural officer, Northern
Rhodesia ; F. R. B. Mullan (agricultural officer, Gold Coast), senior agricultural officer, Gold Coast; T. A. Phillips (agricultural officer, Nigeria), principal of schools, Agricultural Department, Nigeria ; R. Smith (agricultural officer, Gold Coast), senior agricultural officer, Gold Coast; G. R. Spurrell (agricultural officer, Gold Coast), senior agricultural officer, Gold Coast; J. O. Torto (agricultural officer, Gold Coast), senior agricultural officer, Gold Coast; S. G. Willimott (chemist (soils), Agricultural Department, Federation of Malaya), senior chemist (soils), Agricultural Department, Federation of Malaya; M. W. Bryce (executive engineer, Nigeria), assistant director, Water Supply Department, Gold Coast; D. H. Lawson (senior executive engineer, Nigeria), deputy director of public works, Kenya; C. E. Prockter (senior electrical engineer, Gold Coast), senior electrical engineer, Nigeria; G. G. K. Setten (assistant conservator of forests, Fiji), assistant conservator of forests, Federation of Malaya; G. F. Elliott (senior veterinary officer, Northern Rhodesia), deputy director of veterinary services, Northern Rhodesia E. F. Peck (chief veterinary officer, Somaliland Protectorate), director, combined agricultural and veterinary services, Somaliland Protectorate; M. H. French (biochemist, Veterinary Department, Tanganyika), adviser to the Hides, Tanning and Allied Industries Bureau, East Africa High Commission; C. E. W. Hoar (pathologist, Grade B, Trinidad), pathologist, Nigeria ; C. J. P. Ionides (game ranger, Tanganyika), senior game ranger, Tanganyika; D. K. Thomas (veterinary officer, Tanganyika), game ranger, Game Department, Tanganyika.

\section{Announcements}

At the inatgural meeting of the British Association at Newcastle upon Tyne on August 31, the honorary degree of D.Sc. of the University of Durham was conferred on Sir John Russell, president of the Association.

Mr. F. BBUNDRETT, chief of the Royal Naval Scientific Service, has been appointed to succeed Sir Edward Appleton as chairman of the Interdepartmental Scientific Panel set up in 1946 under the White Paper on the Scientific Civil Service.

IN connexion with the Goethe bicentenary celebra. tions, an exhibition illustrating the views of Goethe on plant metamorphosis and on colour has been arranged by the Goethean Science Foundation, Clent, Stourbridge, Worcestershire, and will be open at the Rudolf Steiner House, 35 Park Road, Baker Street, London, N.W.1, during September 15-24.

To promote and encourage scientific and technical research in connexion with the textile industry, the Textile Institute is offering a limited number of research studentships to holders of the associateship of the Institute who are employed in the teaching or practice of textile techmology, and to members qualified to undertake research, generally on a parttime basis, at approved universities and colleges. Further particulars are available from the Textile Institute, 16 St. Mary's Parsonage, Manchester 3.

Erratum. In the article "Effect of Low Temperature on the Absorption Spectra of Hæmoproteins with Observations on the Absorption Spectrum of Oxygen", Nature, August 13, p. 258, the position of the second band of oxygen should read $577 \mathrm{~m} \mu$ throughout and not $557 \mathrm{~m} \mu$. 